\title{
An updated data on the bionomics of pomegranate fruit borer, Deudorix epijarbas (Moore, 1858) (Lepidoptera: Lycaenidae), infesting pomegran- ates in Kashmir
}

\author{
Insha YOUSUF ${ }^{1,2}$ and Abdul A. BUHROO ${ }^{1}$
}

Received February 01, 2020; accepted September 01, 2020. Delo je prispelo 01. februarja 2020, sprejeto 01. septembra 2020.

An updated data on the bionomics of pomegranate fruit borer, Deudorix epijarbas (Moore, 1858) (Lepidoptera: Lycaenidae), infesting pomegranates in Kashmir

Abstract: Pomegranate fruit borer, Deudorix epijarbas (Moore, 1858) (Lepidoptera: Lycaenidae) is a destructive pest of pomegranate affecting the quality as well as quantity of its fruits. The pest and its other allied species are nuisance to pomegranate cultivation throughout India, particularly in hilly state of Jammu \& Kashmir. The aim of present investigation was to study the bionomics of pomegranate fruit borer in laboratory, which included the studies on its morphometry and extent of different developmental stages in the life cycle of pest, for developing a sound management plan against it. The results revealed that the eggs are laid by females singly on fruits, stalks, leaves and flower buds. On hatching, emerging larva bores in to fruits and feed on its pulp thus rendering them unfit for trade. The pest passed through five larval instars of different duration and the total larval period was $32.20 \pm 1.87(\mathrm{SD})$ days. The larval stage was followed by pupal stage which lasted for $9.50 \pm$ 1.84 (SD) days. Furthermore, the longevity of adult male and female butterflies was recorded as $9.20 \pm 1.73$ (SD) and $13.20 \pm$ 1.43 (SD) days respectively. The study thus provides information necessary for development and implementation of different control strategies in IPM of pomegranate fruit borer.

Key words: pomegranate; Deudorix epijarbas; bionomics; morphometry; larval instars
Dopolnjeni podatki o bionomiki zavijača granatnega jabolka Deudorix epijarbas (Moore, 1858) (Lepidoptera: Lycaenidae) v Kašmirju

Izvleček: Zavijač granatnega jabolka, Deudorix epijarbas (Moore, 1858) (Lepidoptera: Lycaenidae) je uničujoč škodljivec, ki vpliva na kakovost in količino plodov. Ta in sorodne vrste škodljivcev predstavljajo težave pri gojenju granatnega jabolka širom Indije, še posebej v hriboviti državi Jammu \& Kashmir. Namen raziskave je bil preučiti bionomiko zavijača granatnega jabolka v laboratoriju glede na morfometrijo in obseg njegovih razvojnih štadijev v življenskem ciklu za razvoj metod dobrega upravljanja s škodljivcem. Rezultati so pokazali, da samice ležejo jajčeca posamično na plodove, peclje, liste in cvetne brste. Po izleganju se ličinke zavrtajo v plodove, v katerih se hranijo s pulpo in jih s tem naredijo neprimerne za prodajo. Škodljivec ima pet razvojnih stopenj ličinke $\mathrm{z}$ različnim trajanjem, celotno obdobje ličinke je trajalo $32,20 \pm 1,87$ (SD) dni. Stopnji ličinke je sledilo obdobje bube, ki je trajalo $9,50 \pm 1,84$ (SD) dni. Življenska doba odraslih samcev in samic je bila 9,20 \pm 1,73 (SD) in 13,20 $\pm 1,43$ (SD) dni. Raziskava prispeva potrebne informacije za razvoj in uporabo različnih strategij nadzora pri integriranem upravljanju zavijača granatnega jabolka.

Ključne besede: granatno jabolko; Deudorix epijarbas; bionomika; morfometrija; razvojne stopnje ličinke

1 University of Kashmir, Department of Zoology, Division of Entomology, Srinagar, Jammu and Kashmir, India

2 Corresponding author, e-mail: inshayousuf444@gmail.com 


\section{INTRODUCTION}

Pomegranate is an ancient sacred fruit belonging to genus Punica of family Punicaceae. It is regarded as a crop of arid and semi-arid regions because of its adaptability to diverse soil and climatic stresses. Pomegranate trees are valued for its products, which have immense nutritional, medicinal and industrial significance (Negi et al., 2003 and Sumner et al., 2005). However, this fruit tree is susceptible to damage inflicted by various insect pests reducing quality and quantity of its products (Ismail et al., 1989). Among them, the damage caused by pomegranate fruit borer, Deudorix epijarbas (Moore, 1858), is enormous throughout India. In Kashmir valley, this pest has been recorded as a serious and predominant pest of pomegranate fruits (Zaka- ur- Rab, 1980). During $20^{\text {th }}$ century, pomegranate cultivation was carried out on large scale in the valley but its plantations succumbed to the attack by pomegranate butterfly. Nowadays, sporadic cultivation is prevalent in certain regions of Kashmir. The pest attack is from the onset of fruiting season til its completion. The larvae bore their way in pomegranate fruits and feed on pulp and seeds making the fruits sensitive to secondary infections of fungus and bacteria. In the fields, infested fruits are detected by the presence of holes on them, through which larvae exude their faecal matter, conferring these fruits an odious stink. As a result, the infested fruits become totally unfit for human consumption and thus impair their trade.

Recently, there is a renewed surge in pomegranate consumption following the assertion of its health benefits. It is deemed a rich source of antioxidants, vitamins, potassium, calcium, magnesium, iron and zinc as has been confirmed by findings of Gil et al.(2000) Aviram \& Dornfeld (2001) and Haidari et al. (2009). Dietary supplementation with pomegranate is believed to prevent cancer (Afaq et al., 2005). Its fruits have antimicrobial, antimutagenic and antioxidant activities (Negi et al., 2003). Furthermore, it has been used in commercial cosmetic preparations on a large scale (Kim et al., 2002). As a result of this increased demand, new plantations are being established throughout the world. This results in higher risk of infestation of pomegranates by insect pests in general and by fruit borers in particular. Successful management strategy requires thorough knowledge on different aspects of insect pest. So far, little work is done on the bionomics of pomegranate fruit borer, D. epijarbas from Kashmir. Therefore, the present investigation was carried out to analyze the biology of $D$. epijarbas on pomegranate in laboratory at room temperature so as to replicate natural environmental conditions necessary for furnishing peak infestation of pomegranate fruit borer, for devising an opportune management strategy against the pest.

\section{MATERIAL AND METHODS}

To study the various aspect of biology, a stock culture of pomegranate fruit borer, D. epijarbas was maintained in Entomology Research Laboratory of Department of Zoology, University of Kashmir. The detailed methodology employed for the study is given below.

\subsection{STOCK CULTURE OF D. epijarbas}

The infested fruits were collected from Kashmir University Botanical Garden (KUBG) having geographic coordinates $\left(34^{\circ} 07^{\prime} 40.66^{\prime \prime} \mathrm{N}, 74^{\circ} 50^{\prime} 11.46^{\prime \prime} \mathrm{E}\right.$ and $\left.5214 \mathrm{ft}\right)$ and Noor Bagh located at $34^{\circ} 04^{\prime} 27.26^{\prime \prime} \mathrm{N}, 74^{\circ} 48^{\prime} 12.80^{\prime \prime} \mathrm{E}$ and $5538 \mathrm{ft}$. The infested fruits were identified by the presence of entry holes made by larvae of this particular pest species. For studying different biological parameters of pomegranate fruit borer, D. epijarbas (Moore, 1858) in laboratory, the methodology of Bhumannavar and Viraktamath (2001) was followed. The collected fruits were then kept in large glass jars open at one end (Fig.1a) under ambient room temperature of $28.55 \pm 2.83^{\circ} \mathrm{C}$ and relative humidity of $75.15 \pm 6.06 \%$. The open end of jar was covered with muslin cloth for ventilation and to prevent the attack of parasites and fungi. Pomegranate fruits were provided to these larvae and the exuded faecal matter was removed from these jars on daily basis (Fig. 1b). The larvae then transformed into pupae and were kept under same rearing conditions till the emergence of adults. The adult male and female butterflies were then shifted carefully to separate rearing jars, provided with fresh pomegranate twigs and calyx. Observations regarding duration of mating, preoviposition, egg laying (oviposition) and postoviposition were recorded under laboratory conditions. The fecundity and adult longevity of both male and female butterflies was also observed and recorded. Duration of different life stages $v i z$. larval instars, pupation and adult stage was recorded from eggs laid in laboratory. The detailed data on morphometry of different stages of life cycle was also recorded. The cotton swabs soaked in $5 \%$ sucrose solution served as a source of food and water for studying the behaviour of adult butterflies during the course of study.

\subsubsection{STUDY OF DIFFERENT BIOLOGICAL PA- RAMETERS OF D. epijarbas}

Observations with regard to different developmental stages were recorded from these freshly laid eggs on pomegranate twigs and calyx under laboratory conditions. 

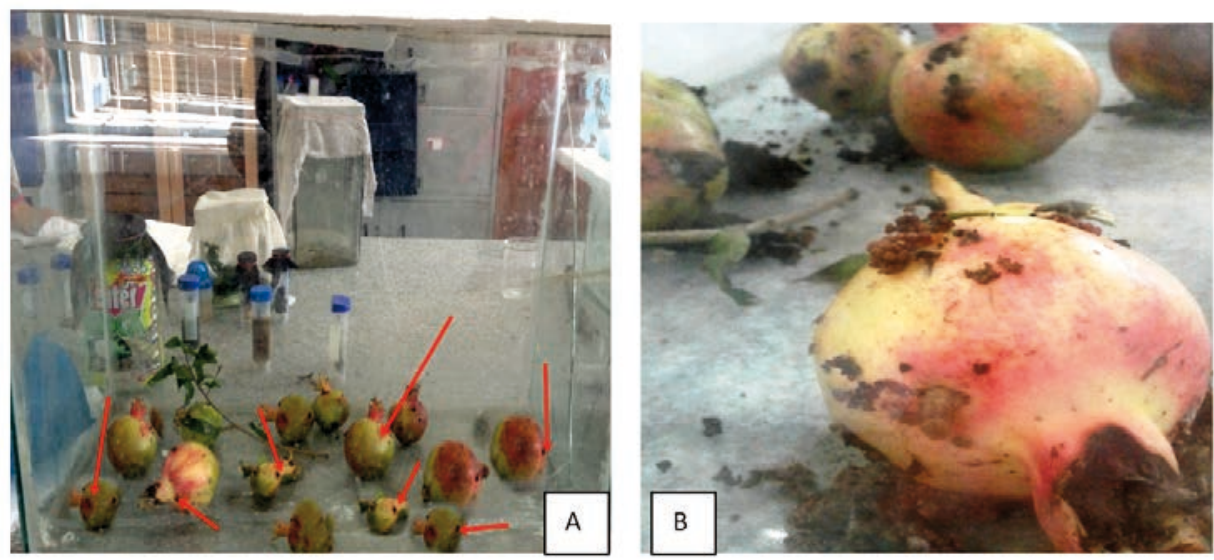

Figure 1: A: Rearing of fruit borer infested pomegranates in laboratory. B: Posterior region of D. epijarbas larva visible from the holes of infested fruits and exuded faecal matter.

\subsubsection{Eggs}

For the study of incubation period of eggs, 10 freshly laid eggs were taken from the stock culture and kept in separate Petri dish and observed daily till the emergence of young larvae. The observations on hatching percentage along with the changes in colour and shape of eggs were recorded as well.

\subsubsection{Larval period}

A total of 10 freshly emerged young larvae were transferred to separate glass jars using a fine camel hair brush and fresh food (pomegranate fruits cut into two halves) was provided to them on daily basis. These larvae were kept under constant observation to record the number and duration of different larval instar. The change in larval instar was substantiated by change in its colour which was further validated by presence of exuvium of head capsule on infested fruit. Duration of larval period (i.e. number of days taken by a larva since its emergence from egg up to its pupation) was also computed. In separate experiment, head capsule width for each larval instar was measured to separate different larval instars (Dyar, 1890). In the later stages, larvae stops feeding and become sluggish which signals the initiation of pupal stage.

\subsubsection{Pupal period}

Studies on duration of pupal period were carried out on 10 fully grown larvae that were kept in separate beakers and the number of days from termination of larval period till the appearance of adults were counted and recorded as pupal period. Observations regarding the colour and shape of pupae were also recorded.

\subsubsection{Adult longevity}

Total life span of adult i.e. number of days from emergence of adults to their death was regarded as longevity of adult butterflies. Observations on longevity were recorded for both male and female butterflies.

\subsubsection{Ovipositional period and fecundity}

To determine the ovipositional period, the eggs laid by female were observed and removed daily til the death of female butterfly. Fecundity is the total number of eggs laid by a single female butterfly during its lifetime. Both experiments were replicated 10 times.

\subsubsection{Life cycle}

Based on the duration of different stages in the life cycle of pomegranate fruit borer viz. egg, larva, pupae and adult time period required for the completion of life cycle was recorded..

\subsubsection{Statistical analysis}

The data obtained from the experiments was arranged in tables. The mean, range and Standard deviation of the readings was computed using SPSS software (16.0). 


\section{RESULTS}

The observations on biology of D. epijarbas are presented under following headings.

\subsection{EGGS}

The female butterfly laid eggs singly on fruits, stalks, leaves and flower buds (Fig. 2a). These eggs were light greenish in colour when fresh, more or less rounded in shape and turned white just before hatching. The diameter of eggs ranged from 0.90 to $1.15 \mathrm{~mm}$ with an average of $1.04 \mathrm{~mm} \pm 0.02$ (SE) (Table 1). The incubation period of eggs varied from 8 to 12 days with a mean of 10.33 days \pm 1.02 (SE) (Table 3 ).

\subsection{LARVAL PERIOD}

The destructive stage of this pest is represented by its different larval instars (Fig. 2b). The pest was found to pass through five larval instars on pomegranate fruits in laboratory before transforming into pupa. Head capsule width of each larval instar was used to determine the larval instar (Table 2). The duration of each larval instar and measurements of dif- ferent developmental stages is given in Tables 3 \& 4 respectively.

Newly hatched larvae were cylindrical, light brown in colour and possessing a triangular black structure on thoracic segments. The body of larva was covered with dense white hairs which were longer in abdominal segments. The developmental period of first larval instar ranged from 4 to 6 days with an average of 4.95 days \pm 0.76 (SD) whereas the average body length and width was recorded as $3.94 \mathrm{~mm} \pm 0.42$ (SD) and $0.88 \mathrm{~mm} \pm 0.08$ (SD) respectively.

The second instar larva differed markedly from first instar in size and colour. This larval instar was dark brown in colour with less dense body hairs. Length of second larval instar of D. epijarbas ranged from 5.50 to $7.94 \mathrm{~mm}$ with an average of $6.79 \pm 0.82$ (SD) $\mathrm{mm}$ while the breadth ranged from 1.25 to $1.50 \mathrm{~mm}$ with a mean of $1.37 \pm 0.08(\mathrm{SD}) \mathrm{mm}$ (Table 4). Average duration of second instar larvae was found to be $5.45 \pm 0.83(\mathrm{SD})$ days, and ranged from 4.0-6.5 days.

Third larval instar was analogous to previous larval instar except in its dimensions. The developmental period of third instar larvae varied from 5 to 7.5 days with an average of $6.40 \pm 0.87$ (SD) days (Table 3). The length and width of this larval instar ranged from 9.30 to $12.95 \mathrm{~mm}$ with an average of $10.92 \pm 1.24$ (SD) $\mathrm{mm}$,

Table 1: Morphometric measurements of egg of pomegranate fruit borer, D. epijarbas

\begin{tabular}{|c|c|c|c|c|c|c|c|c|c|c|c|c|}
\hline \multirow{2}{*}{$\begin{array}{l}\text { Parameter } \\
\text { Egg diameter } \\
(\mathrm{mm})\end{array}$} & \multicolumn{10}{|c|}{ Observations } & \multirow{2}{*}{\multicolumn{2}{|c|}{$\begin{array}{ll}\text { Mean }( \pm S E)^{\star} & \text { Range } \\
1.04( \pm 0.02) & 0.90-1.15\end{array}$}} \\
\hline & I & II & III & IV & $\mathrm{V}$ & VI & VII & VIII & IX & $\mathrm{X}$ & & \\
\hline & 1.00 & 1.02 & 1.15 & 0.90 & 1.09 & 1.04 & 1.07 & 1.03 & 1.06 & 1.05 & & \\
\hline
\end{tabular}

${ }^{*}$ Mean of 10 replications, figure in parenthesis are standard error.

Table 2: Head capsule width of different larval instars of pomegranate fruit borer, D. epijarbas

\begin{tabular}{llllll}
\hline & & Mean observed head & & \\
Larval instars & No. of larvae observed & width $( \pm$ SE) & Range & Expected head width ${ }^{*}$ & Difference $^{2}$ \\
\hline I & 10 & $0.412( \pm 0.017)$ & $0.34-0.49$ & 0 \\
II & 10 & $0.695( \pm 0.025)$ & $0.54-0.78$ & 0.688 & 0.007 \\
III & 10 & $1.192( \pm 0.015)$ & $1.12-1.26$ & 1.16 & 0.032 \\
IV & 10 & $1.770( \pm 0.022)$ & $1.66-1.86$ & 1.99 & 0.218 \\
V & 10 & $2.447( \pm 0.0345)$ & $2.20-2.60$ & 2.95 & 0.503 \\
\hline
\end{tabular}

*Expected head capsule width established by Dyar's ratio $(1.67 \mathrm{~mm})$. Multiplying Dyar's ratio with the observed head capsule width of 1 st instar larva gives the expected head capsule width of 2nd larval instar which when multiplied again with Dyar's ratio gives expected head capsule width of 3rd larval instar and so on.

Mean observed head capsule width of 1st larval instar $(\mathrm{N}=10)=0.412 \mathrm{~mm}$

Mean observed head capsule width of 2nd larval instar $(\mathrm{N}=10)=0.695 \mathrm{~mm}$

Growth ratio (Dyar's ratio) $=$ Head capsule width of 2nd larval instar $/$ Head capsule width of 1 st larval instar $=0.695 / 0.412=1.67 \mathrm{~mm}$ 
and 2.15 to $2.89 \mathrm{~mm}$ with an average of $2.50 \pm 0.26$ (SD) $\mathrm{mm}$ respectively.

The colour of body became considerable darker in stout fourth instar larvae. Average duration of fourth larval instar was $7.10 \pm 0.39$ (SD) days whereas mean body length was $15.58 \pm 0.80$ (SD) $\mathrm{mm}$ with an average width of $3.63 \pm 0.31$ (SD) $\mathrm{mm}$.

Fully mature larva was stouter, slothful and dark green in colour and the final instar lasted for $8.35 \pm$ 0.58 days ( 7.5 to 9.0 days). Average body length of fifth larval instar was $19.54 \pm 1.53$ (SD) $\mathrm{mm}$ (17.00 to $21.72 \mathrm{~mm}$ ) whereas the average breadth varied from 5.38 to $6.77 \mathrm{~mm}$ with an average of $5.90 \pm 0.50$ (SD) $\mathrm{mm}$. Thus, the total larval period of D. epijarbas on pomegranates in laboratory ranged between 29.0 to 35.0 days with an average of $32.20( \pm 1.87)$ days (Table $3)$.

A fully matured larva of pomegranate fruit borer impeded its feeding, became smaller in size and got transformed into pre- pupal stage. The pre pupa was dark green in colour with brown head. The duration of this stage varied from 2.5 to 3.5 days with an average of $3.00 \pm 0.41(\mathrm{SD})$ days.

\subsection{PUPAL PERIOD}

The pupa of D. epijarbas was initially light brown in colour and gradually changed its colour to dark brown (Fig. 2c). The length of pupal stage varied from 13.22 to $16.00 \mathrm{~mm}$ and average length was found to be $14.57 \pm 0.92(\mathrm{SD}) \mathrm{mm}$. The pupal breadth ranged between 6.00 and $6.96 \mathrm{~mm}$ with an average of 6.55 \pm 0.29 (SD) $\mathrm{mm}$. The duration of pupal stage varied from 7.0 to 12.0 days with a mean of $9.50 \pm 1.84$ (SD) days. Pupation was observed to occur on or inside the damaged fruits as well as on the sides and corners of

Table 3: Duration of different developmental stages of D. epijarbas in laboratory

\begin{tabular}{llll}
\hline Parameters & No. of observations & Range & Mean \pm SD \\
\hline Incubation period & 10 & $7.0-11.0$ & $8.75( \pm 1.38)$ \\
$1^{\text {st }}$ larval instar & 10 & $4.0-6.0$ & $4.95( \pm 0.76)$ \\
$2^{\text {nd }}$ larval instar & 10 & $4.0-6.5$ & $5.45( \pm 0.83)$ \\
$3^{\text {rd }}$ larval instar & 10 & $5.0-7.5$ & $6.40( \pm 0.87)$ \\
$4^{\text {th }}$ larval instar & 10 & $6.5-7.5$ & $7.10( \pm 0.39)$ \\
$5^{\text {th }}$ larval instar & 10 & $7.5-9.0$ & $8.35( \pm 0.58)$ \\
Total larval period & 10 & $29.0-35.0$ & $32.20( \pm 1.87)$ \\
Pre- pupa & 10 & $2.5-3.5$ & $3.00( \pm 0.41)$ \\
Pupa & 10 & $7.0-12.0$ & $9.50( \pm 1.84)$ \\
Male adult longevity & 10 & $7.0-11.5$ & $9.20( \pm 1.73)$ \\
Female adult longevity & 10 & $11.0-15.0$ & $13.20( \pm 1.43)$ \\
Total life span (Male) & 10 & $58.5-69.5$ & $62.65( \pm 3.18)$ \\
Total life span (Female) & 10 & $62.0-74.5$ & $66.65( \pm 3.68)$ \\
\hline
\end{tabular}

$\mathrm{SD}=$ Standard deviation, figures in parenthesis are standard deviation of mean

Table 4: Measurements of different life stages in pomegranate fruit borer, $D$. epijarbas under laboratory conditions

\begin{tabular}{lllll}
\hline Developmental stage & Mean length $( \pm \text { SD })^{*}$ & Range & Mean breadth $( \pm \text { SD })^{*}$ & Range \\
\hline $1^{\text {st }}$ larval instar & $3.94( \pm 0.42)$ & $3.50-4.50$ & $0.88( \pm 0.08)$ & $0.75-1.00$ \\
$2^{\text {nd }}$ larval instar & $6.79( \pm 0.82)$ & $5.50-7.94$ & $1.37( \pm 0.08)$ & $1.25-1.50$ \\
$3^{\text {rd }}$ larval instar & $10.92( \pm 1.24)$ & $9.30-12.95$ & $2.50( \pm 0.26)$ & $2.15-2.89$ \\
$4^{\text {th }}$ larval instar & $15.58( \pm 0.80)$ & $14.44-16.70$ & $3.63( \pm 0.31)$ & $3.07-4.20$ \\
$5^{\text {th }}$ larval instar & $19.54( \pm 1.53)$ & $17.00-21.72$ & $5.90( \pm 0.50)$ & $5.38-6.77$ \\
Pupa & $14.57( \pm 0.92)$ & $13.22-16.00$ & $6.55( \pm 0.29)$ & $6.00-6.96$ \\
\hline
\end{tabular}

${ }^{*}$ Mean of 10 replication/ developmental stage, figures in parenthesis are standard deviation. 
Table 5: Measurements of adult male and female D. epijarbas

\begin{tabular}{lllll}
\hline Adult & Mean body length in $\mathrm{mm}( \pm \mathrm{SD})^{\star}$ & Range & Mean wing expanse in mm $( \pm \mathrm{SD})^{\star}$ Range \\
\hline Male & $18.54( \pm 1.57)$ & $16.50-20.93$ & $38.25( \pm 1.52)$ & $36.40-40.50$ \\
Female & $22.97( \pm 1.07)$ & $21.65-24.66$ & $42.26( \pm 1.26)$ & $40.58-44.50$ \\
\hline
\end{tabular}

${ }^{*}$ Mean of 10 replication/ individual, figures in parenthesis are standard deviations.

Table 6: Duration of different biological phenomenon in the life cycle of pomegranate fruit borer, D. epijarbas

\begin{tabular}{|c|c|c|c|c|c|}
\hline Observations (N) & Mating (minutes) & Pre-oviposition (days) & Oviposition (days) & Post-oviposition (days) & Fecundity(number) \\
\hline I & 59 & 3 & 3.5 & 7.5 & 27 \\
\hline II & 57 & 3.5 & 4 & 4 & 24 \\
\hline III & 65 & 4 & 3 & 5.5 & 23 \\
\hline IV & 66 & 3 & 4.5 & 4 & 29 \\
\hline $\mathrm{V}$ & 58 & 4 & 4.5 & 5 & 20 \\
\hline VI & 63 & 4 & 3 & 6.5 & 25 \\
\hline VII & 62 & 3.5 & 3 & 6 & 29 \\
\hline VIII & 64 & 3 & 3.5 & 5 & 22 \\
\hline IX & 59 & 3 & 4 & 7 & 26 \\
\hline $\mathrm{X}$ & 57 & 3.5 & 3.5 & 5.5 & 28 \\
\hline Mean \pm SD & $61.00 \pm 3.40$ & $3.65 \pm 0.44$ & $3.65 \pm 0.58$ & $5.6 \pm 1.17$ & $25.30 \pm 3.06$ \\
\hline
\end{tabular}

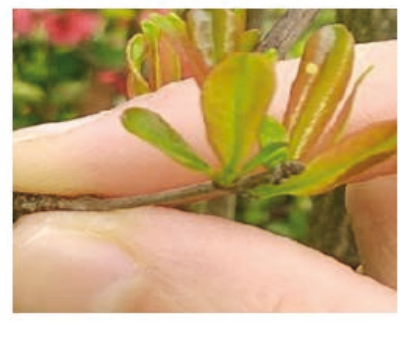

$$
\text { a. Egg }
$$

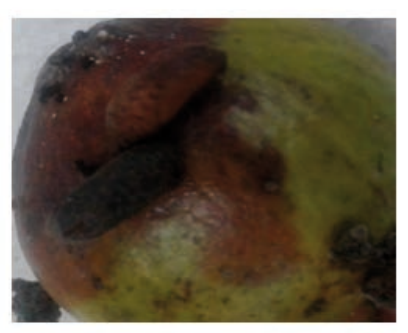

c. Pupa

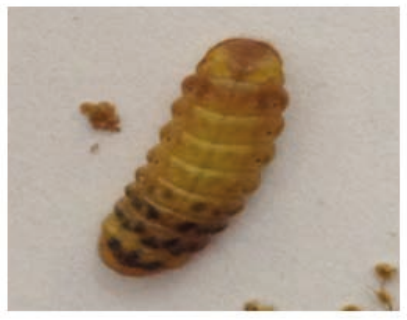

b. Larva

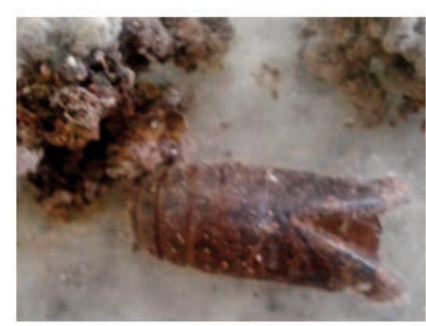

d. Empty pupal case

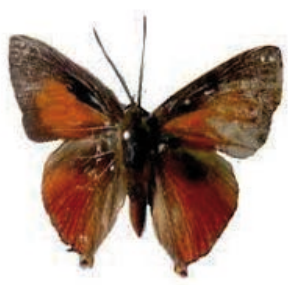

e. Adult

Figure 2 (a - e): Different developmental stages in the life cycle of D. epijarbas. 
rearing jar. Adult butterflies emerged by splitting the pupal covering dorsally (Fig. 2d and 2e).

\subsection{ADULTS}

Sexual dimorphism is conspicuous in adult pomegranate fruit borer, D. epijarbas. The female butterflies were larger in size with longer wing expanse than their male counterparts. The females were dull brown in colour and measured $22.97 \pm 1.07$ (SD) mm (Table 5). Average width of female butterfly including wing span was observed to be $42.26 \pm 1.26$ (SD) $\mathrm{mm}$ with longevity of $13.20 \pm 1.43$ (SD) days. The males were brick red in colour having an average body length of $18.54 \pm 1.57$ (SD) $\mathrm{mm}$. The width across wings was found to be $38.25 \pm 1.52$ (SD) $\mathrm{mm}$ and longevity of $9.20 \pm 1.73$ (SD) days (Table 5).

The preoviposition, oviposition and post oviposition period of female D. epijarbas ranged from 3 to 4 days with an average of $3.45 \pm 0.44$ (SD) days, 3 to 4.5 days with an average of $3.65 \pm 0.58$ (SD) days and 4 to 7.5 days with an average of $5.6 \pm 1.17$ (SD) days respectively. Fecundity of pomegranate fruit borer ranged between 20 to 29 eggs with a mean of $25.30 \pm 3.06$ (SD) eggs (Table 6).

The total life cycle of D. epijarbas in laboratory was observed to vary from 58.5 to 69.5 days for males and mean of $62.65 \pm 3.18$ (SD) days while on the contrary, the total life cycle of females ranged from 62.0 to 74.5 days with a mean of $66.65 \pm 3.68$ (SD) days (Table 3).

\section{DISCUSSION}

A number of studies have been carried on the biological parameters of Deudorix (=Virachola) isocrates (Fabricius, 1793) by various workers viz. Kabre and Mohalkar (1992), Thirumurugan (1992), Karuppuchamy et al. (1998), Singh \& Singh (2001), Tiwari \& Mishra (2007), Bhut et al. (2013) and Chettry et al. (2015). However, there are reports of preliminary studies carried out on biology of $D$. epijarbas, an allied species of $D$. isocrates, by Zak- ur- rab (1980), Verma (1985) and Dutta (1992).

In the present experiments, mean incubation period of $8.75 \pm 1.38$ days was recorded for the eggs of $D$. epijarbas. Gharbi (2010) reported a lesser incubation period of $5.23 \pm 0.32$ days for another species of pomegranate fruit borer, V. livia Klug, 1834 in Tunisia. This disparity may be because of difference in pest species, variability of host plant, agroclimatic conditions or latitudinal clines of place at which the study was carried out.

The present study on the biology of pomegranate fruit borer, D. epijarbas has shown that larvae of the pest pass through five larval instars on pomegranates in laboratory. Change in larval instars was accomplished on the basis of head capsule width of larvae, which unlike average larval weight did not overlap and thus was an accurate indicator of larval development. In present investigation, total larval period of $D$. epijarbas varied between 29.0 and 35.0 days with an average of $32.20 \pm 1.87$ (SD) days. These results are somewhat in agreement with the findings of Dutta (1992) and Mohi- ud- din et al. (2014) who both worked on same species of pomegranate fruit borer in Kashmir. At the end of larval period, larvae entered a non- motile, non- feeding pre- pupal phase that lasted for 3 days preceding the formation of pupa.

Our study revealed that pupation occurred inside or on the skin of fruit, at corners and sides of rearing jar and lasted for 7 to 12 days with a mean of $9.50 \pm 1.84$ (SD) days. Similar observations were made by Tiwari \& Mishra (2007) and Chettry et al. (2015) for D. isocrates on different hosts implying that plant fed to larvae during rearing, has no effect for pupal development of genus Deudorix.

The present study showed that there was a difference in female and male longevity. In our experiments, adult females lived longer than adult males with mean longevity of 13.20 and 9.20 days respectively. The average life span of males was found to be $62.65 \pm 3.18$ (SD) days (58.5 to 69.5 days), whereas females had average life span of $66.65 \pm 3.68$ days (62.0 to 74.5 days). Variations in colour patterns of male and female butterfly found in the present study are in consistency with the previous studies of Zaka- ur- rab (1980), Verma (1985) and Dutta (1992).

Our study revealed that body length in males ranged from 16.50 to $20.93 \mathrm{~mm}$ with an average of $18.54 \pm 1.57$ (SD) $\mathrm{mm}$ whereas for females, average body length was $22.97 \pm 1.07$ (SD) $\mathrm{mm}$ ( 21.65 to $24.66 \mathrm{~mm}$ ). The average width across wings in male was $38.25 \pm 1.52$ (SD) $\mathrm{mm}$ (36.40 to $40.50 \mathrm{~mm}$ ) and in female, wing expanse ranged from 40.58 to $44.50 \mathrm{~mm}$ with a mean of $42.26 \pm 1.26$ (SD) $\mathrm{mm}$. These results are in line with the observations of Singh \& Singh (2001) and Tiwari \& Mishra (2007) about body length and wing expanse for a different species of pomegranate fruit borer, $D$. isocrates on aonla, Phyllanthus emblica L..

The present study revealed that the mean pre-oviposition, oviposition and postoviposition period of $D$. epijarbas in laboratory were $3.45 \pm 0.44(\mathrm{SD}), 3.65 \pm$ 0.58 (SD) and $5.60 \pm 1.17$ (SD) days respectively. From our study, the egg laying capacity of female butterfly was found to vary from 20 to 29 eggs with a mean of 25.30 \pm 3.06 (SD) eggs. Conversely, the study of Zaka- ur- rab (1980) have shown that female butterfly laid only 4 eggs. Total life cycle was worked out to take 62.65 days in males and 66.65 days in females, implying that fruit borer 
can complete 2- 4 generations during fruiting season of pomegranate.

\section{CONCLUSIONS}

The present study thus provides important information about development, longevity and other biological parameters of D. epijarbas. In the present study, mean diameter of eggs of the pest was found as $1.04( \pm 0.02)$ $\mathrm{mm}$. Further, the duration of $1^{\text {st }}, 2^{\text {nd }}, 3^{\text {rd }}, 4^{\text {th }}$ and $5^{\text {th }}$ larval instars was $4.95( \pm 0.76), 5.45( \pm 0.83), 6.40( \pm 0.87), 7.10$ $( \pm 0.39)$ and $8.35( \pm 0.58)$ days respectively. The female butterflies showed longer adult longevity $(13.20 \pm 1.43$ days) as well as total life span (66.65 \pm 3.68 days) than their male counterparts with adult longevity of $9.20( \pm$ $1.73)$ days and total life span of $62.65( \pm 3.18)$ days. The body length and wing expanse was recorded as 18.54 ( \pm 1.57) $\mathrm{mm} \& 38.25( \pm 1.52) \mathrm{mm}$ in males and $22.97( \pm$ $1.07) \mathrm{mm}$ and $42.26( \pm 1.26) \mathrm{mm}$ in females. The duration of preoviposition, oviposition and postoviposition was $3.65( \pm 0.44), 3.65( \pm 0.58)$ and $5.60( \pm 1.17)$ days respectively. The present understanding of the biology of this particular pest species would help in its management and control. During the current experiments, a gap of few days was observed between oviposition and penetration of fruits by first instar larva which may prove significant while formulating its control strategies. Therefore, further studies should try to exploit this gap and during the assessment of different control strategies focus should be on preventing the entry of larvae in pomegranate fruits.

\section{REFERENCES}

Afaq, F., Saleem, M. and Mukhtar, H. (2003). Pomegranate fruit extract is a novel agent for chemoprevention: Studies in mouse skin. $2^{\text {nd }}$ Annual AACR International Conference on Frontiers in Cancer Prevention Research, 26- 30 October. Cancer Epidemiology and Biomarkers and Prevention, 12, 1351-1353. https://doi.org/10.1016/S0021-9150(01)004129

Aviram, M. and Dornfeld, L. (2001). Pomegranate juice consumption inhibits serum angiotensin converting enzyme activity and reduces systolic blood pressure. Atherosclerosis, 158, 195- 198.

Bhumannavar, B. S. and Viraktamath, C. A. (2001). Rearing techniques for three species of Othreis (Lepidoptera: Noctuidae) and their ectoparasitoid, Eupletrus maternus Bhatnagar (Hymenoptera: Eulophidae). Journal of Biological Control, 15(2), 189- 192.

Bhut, J. B., Borad, P. K. and Gadhiya, H. A. (2013). Bionomics and evaluation of different biocides against anar butterfly, Virachola isocrates (Fabricius) infesting pomegranate. International Journalof Plant Protection, 6(2), 338-343.
Chhetry, M., Gupta, R. and Tara, J.S. (2015). Bionomics of Deudorix isocrates Fabricius (Lepidoptera: Lycaenidae), a new potential host of sweet orange, Citrus sinensis L. Osbeck in J \& K, India. International Journal Science and Nature, 6(2), 238-241.

Dutta, T. S. (1992). Biology and management of pomegranate fruit borer, Deudorix epijarbas (Moore). Thesis submitted to Sher- e- Kashmir University of Agricultural Sciences and Technology of Kashmir, Shalimar, Srinagar.

Dyar, H. G. (1890). The number of moults of Lepidopterous larvae. Psyche, 5, 420-422. https://doi.org/10.1155/1890/23871

Gharbi, N. (2010). Laboratory rearing of pomegranate fruit butterfly Virachola livia on two host plants in Tunisia. Tunisian Journal Plant Protection, 5, 195-199.

Gil, M. I., Tomas- Barberan, F. A., Hess- Pierce, B., Holcroft, D. M. and Kader, A. A. (2000). Antioxidant activity of pomegranate juice and its relationship with phenolic composition and processing. Journal of Agricultural \& Food Chemistry, 48, 4581-4589. https://doi.org/10.1021/jf000404a

Haidari, M., Ali, M., Casscells, S.W. and Madjid, M. (2009). Pomegranate (Punica granatum) purified polyphenol extract inhibits influenza virus and has a synergistic effect with oseltamivir. Phytomedicine, 16(12), 1127-36. https:// doi.org/10.1016/j.phymed.2009.06.002

Ismail, I. I., El- Nagar, S. and Attia, A. A. (1989). The aphid fauna of fruit trees in Egypt. African Journal Agricultural Science, 13(1-2), 1-7.

Kabre, G. B. and Moholkar, P. R. (1992). Studies on life history of pomegranate fruit- borers, Virachola isocrates Fabr. Journal of Insect Science, 5(2), 213.

Karuppuchamy, P., Balasubramaniam, G. and Babu, P. C. S. (1998). The biology of pomegranate fruit borer, Deudorix isocrates. The Madras Agricultural Journal, 5(6), 252-256.

Kim, N. D., Mehta, R., Yu, W., Neeman, I., Livney, T., Amichay, A., Poirier, D., Nicholls, P., Kirby, A., Jiang, W., Mansel, R., Ramachandran, C., Rabi, T., Kaplan, B. and Lansky, E. (2002). Chemopreventive and adjuvant therapeutic potential of pomegranate (Punica granatum) for human breast cancer. Breast Cancer Research and Treatment, 71, 203-217. https://doi.org/10.1023/A:1014405730585

Mohi- ud- din, S. (2014). Current status, life cycle and development of IPM module of fruit borer, Deudorix epijarbas (Moore) on pomegranate. Thesis submitted to Sher- eKashmir University of Agricultural Sciences and Technology of Kashmir, Shalimar, Srinagar.

Murugan, M. and Thirumurugan, A. (2001). Studies on ecofriendly approaches to manage pomegranate fruit borer. Plant Protection. Bulletin, 5(3), 13-15.

Negi, P. S., Jayaprakasha, G. K. and Jena, B. S. (2003). Antioxidant and antimutagenic activities of pomegranate peel extracts. Food Chemistry, 80, 393-397. https://doi. org/10.1016/S0308-8146(02)00279-0

Singh, H. B. and Singh, S. B. (2001). Biology of Deudorix isocrates on its new potential host, aonla. Indian Journal of Entomology, 63(1), 19-25.

Sumner, M. D., Elliott- Eller, M., Weidner, G., Daubenmier, J. J., Chew, M. H., Marlin, R., Raisin, C. J. and Ornish, D. (2005). Effects of pomegranate juice consumption on myocardial perfusion in patients with coronary heart disease. American 
Journal Cardiology, 96, 810-814. https://doi.org/10.1016/j. amjcard.2005.05.026

Thirumurugan, A. (1992). Studies on insect pests of pomegranate and their control. M. Sc. (Ag.) Thesis, Agricultural College and Research Institute (T. N. A. U.), Killikulam T. N. (India).

Tiwari, A. K. and Mishra. P. (2007). Biology of Deudorix isocrates Fabricius on aonla, Emblica officinalis. Annals of Plant Protection Science, 15(2), 335-337.
Verma, R. R. (1985). Preliminary observations on the biology of pomegranate butterfly, Deudorix epijarbas Moore. Agricultural Science Digest, 5, 1-2.

Zaka- ur- Rab, M. (1980). The cornelian Deudorix epijarbas Moore (Lepidoptera: Lyaenidae) as a serious pest of pomegranate fruits in Kashmir. Journal of Entomological Research, 4, 233-235. 